\begin{tabular}{|l|l|l||}
\hline \multicolumn{2}{|c|}{ PublisherInfo } \\
\hline \hline PublisherName & $:$ & BioMed Central \\
\hline \hline PublisherLocation & $:$ & London \\
\hline \hline PublisherImprintName & $:$ & BioMed Central \\
\hline \hline
\end{tabular}

\title{
Radiation risks
}

\begin{tabular}{|l|c|l||}
\hline \multicolumn{2}{|c|}{ ArticleInfo } \\
\hline \hline ArticleID & $:$ & 4397 \\
\hline \hline ArticleDOI & $:$ & $10.1186 /$ gb-spotlight-20020211-01 \\
\hline \hline ArticleCitationID & $:$ & spotlight-20020211-01 \\
\hline \hline ArticleSequenceNumber & $:$ & 63 \\
\hline \hline ArticleCategory & $:$ & Research news \\
\hline ArticleFirstPage & $:$ & 1 \\
\hline \hline ArticleLastPage & $:$ & 2 \\
\hline \hline & & RegistrationDate : 2002-2-11 \\
\hline ArticleHistory & $:$ & OnlineDate \\
\hline \hline ArticleCopyright & $:$ & BioMed Central Ltd2002-11 \\
\hline \hline ArticleGrants & $:$ & \\
\hline \hline ArticleContext & $:$ & 130593311 \\
\hline \hline
\end{tabular}




\section{Jonathan B Weitzman}

Email: jonathanweitzman@hotmail.com

In the February 8 Science, Dubrova et al. report a study of the genetic risk of ionizing radiation to humans (Science 2002, 295:1037). They studied blood samples from 40 three-generation families living near the Semipalatinsk nuclear test site in Kazakhstan; they looked at eight hypervariable minisatellite probes and compared mutation rates with matched control samples. Dubrova et al., found a statistically significant 1.8 -fold increase in the mutation rate of the exposed population. The highest mutation rates were found in individuals born before 1950, and correlated with exposure to surface explosion tests carried out in the 1940s and 1950s. Germline mutation rates dropped in subsequent generations, reflecting the ban on nuclear weapon tests in 1963.

\section{References}

1. Science, [http://www.sciencemag.org] 